\begin{tabular}{l} 
DUTRNAI, RIS'II \\
(Rekayasa Sistem dan Teknologi Informasi) \\
Vol.3 No. 2(2019) $131-140 \quad$ ISSN Media Elektronik: $2580-0760$ \\
\hline
\end{tabular}

\title{
Perbandingan Akurasi Pengenalan Jenis Beras dengan Algoritma Propagasi Balik pada Beberapa Resolusi Kamera
}

\author{
David Ricardo ${ }^{1}$, Gasim ${ }^{* 2}$ \\ ${ }^{1,2}$ Teknik Informatika, STMIK Global Informatika MDP \\ 12david_ricardo@mhs.mdp.ac.id, ${ }^{2}$ gasim@mdp.ac.id
}

\begin{abstract}
Rice is a staple that is cooked so that it becomes rice for daily consumption. The type of rice that is often used for daily consumption is white rice. There are several types of white rice circulating in the market that are consumed by the public. Each type of rice gives different scent, taste and price. This study compares the accuracy of white rice type recognition based on several camera resolutions. The types of rice used in this study are Jawa Barat rice, Jawa Timur rice, Pandan Wangi rice, Thailand rice and Vietnam rice. The camera resolution used is 5MP, $8 \mathrm{MP}, 12 \mathrm{MP}, 14 \mathrm{MP}$, and 16MP. The shooting distance used is $\pm 9 \mathrm{~cm}$ between the camera and the object of rice. The recognition method used is BackPropagation Artificial Neural Networks, while for feature extraction using the Gray Level Co-occurrence Matrix (GLCM) which consists of contrast, energy, homogeneity, and correlation. The highest results obtained at 12 MP camera resolution with the results of the recognition of 25 of 50 test data and the results of the calculation with confusion matrix obtained an average accuracy of $82 \%$, precision of 55\%, and recall of 50\%. The results of this study can be used as a reference for research that uses objects of similar character, or further research with the same object in developing applications that are ready to use.
\end{abstract}

Keywords:Rice, Recognition, Camera Resolution, GLCM, BackPropagation Artificial Neural Networks.

\begin{abstract}
Abstrak
Beras merupakan bahan pokok yang dimasak atau ditanak sehingga menjadi nasi untuk konsumsi sehari-hari. Jenis beras yang sering digunakan untuk konsumsi sehari-hari adalah beras putih. Terdapat beberapa jenis beras putih yang beredar di pasar yang dikonsumsi masyarakat. Tiap jenis beras tersebut memberikan aroma, rasa, dan harga yang berbeda. Penelitian ini membandingkan tingkat akurasi pengenalan jenis beras putih berdasarkan beberapa resolusi kamera. Jenis beras yang digunakan dalam penelitian ini adalah beras dengan sebutan beras jawa barat, beras jawa timur, beras pandan wangi, beras thailand dan beras vietnam. Resolusi kamera yang digunakan yaitu 5MP, $8 \mathrm{MP}, 12 \mathrm{MP}, 14 \mathrm{MP}$, dan 16MP. Jarak pemotretan yang digunakan $\pm 9 \mathrm{~cm}$ antara kamera dengan objek beras. Metode pengenalan digunakan adalah Jaringan Syaraf Tiruan Propagasi Balik, sedangkan untuk ekstraksi fitur menggunakan Gray Level Co-occurrence Matrix(GLCM) yang terdiri atas contrast, energy, homogeneity, dan correlation. Hasil tertinggi didapatkan pada resolusi kamera $12 \mathrm{MP}$ dengan hasil pengenalan sebanyak 25 dari 50 data uji serta hasil dari perhitungan dengan confusion matrix diperoleh rata-rata accuracy sebesar $82 \%$, precision sebesar $55 \%$, dan recall sebesar $50 \%$. Hasil penelitian ini dapat digunakan sebagai rujukan pada penelitian yang menggunakan objek dengan karakter sejenis, atau penelitian lanjutan dengan untuk objek yang sama dalam pengembangan aplikasi yang siap pakai.
\end{abstract}

Kata kunci:Beras, Pengenalan, Resolusi Kamera, GLCM, Jaringan Syaraf Tiruan Propagasi Balik

(C) 2019 Jurnal RESTI

\section{Pendahuluan}

Beras merupakan makanan pokok yang dihasilkan dari tanaman padi yang ditanam di sawah. Tanaman ini dapat dilihat pada Gambar 1.Beras merupakan bahan pokok yang dimasak atau ditanak sehingga menjadi nasi untuk dikonsumsi oleh sebagian besar masyarakat Indonesia sehari-hari. Jenis beras yang biasa digunakan untuk konsumsi sehari-hari adalah beras putih. Terdapat beberapa jenis beras putih yang beredar di

Diterima Redaksi : 14-05-2019 | Selesai Revisi : 13-07-2019| Diterbitkan Online : 01-08-2019 
pasar yang dikonsumsi masyarakat. Tiap jenis beras sistem saraf biologi, seperti proses informasi pada otak tersebut memberikan aroma, rasa, dan harga yang manusia. Cara kerja JST seperti cara kerja manusia, berbeda.

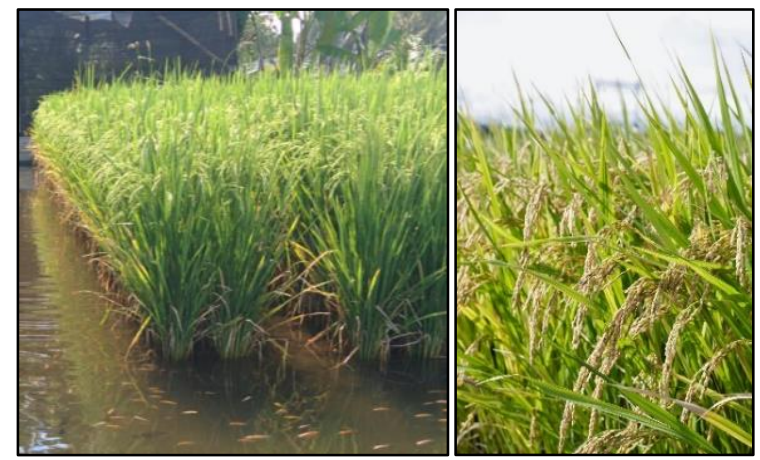

Gambar 1. Tanaman Padi [1][2] yaitu belajar melalui contoh [3].

Penelitian terdahulu yang menggunakan jaringan syaraf tiruan sebagai metode pengenalan diantaranya pada penelitian identifikasi permukaan daun pada tanaman buah tropika dengan parameter input berdasarkan ekstraksi ciri GLCM (Gray Level Co-occurrence Matrix). Hasil akurasi tertinggi didapatkan pada tanaman buah belimbing sebesar 94\% dan akurasi terendah pada tanaman buah nangka sebesar $64 \%$ dan rata - rata akurasi keseluruhan sebesar 90\% [4].

Penelitian identifikasi tiga varietas beras berdasarkan warna dan tekstur menggunakan JST melakukan perbandingan tingkat akurasi untuk tiga metode fitur, yaitu warna, tektur, dan gabungan warna dan tektur.

Secara umum untuk mendapatkan beras adalah setelah Fitur warna yang digunakan adalah R,G,B, sedangkan dipanen kemudian gabah dipisahkan dari merang fitur tekstur yang digunakan adalah ASM, kontras, dengan cara dipukul-pukul atau dengan alat lainnya, korelasi, IDM, dan entropi. Penelitian ini menghasilkan kemudian gabah dikeringkan, dan kemudian gabah tingkat akurasi 54,83\% untuk fitur warna, 100\% untuk digiling untuk memisahkan padi dari beras. Barulah fitur tekstur, dan 97,92\% untuk fitur gabungan warna kemudian beras dipasarkan. dan tekstur [5].

Beras merupakan bahan pokok yang dimasak atau Penelitian klasifikasi mutu buah pisang dengan metode ditanak sehingga menjadi nasi untuk dikonsumsi oleh pengenalan jaringan syaraf tiruan menggunakan sebagian besar masyarakat Indonesia sehari-hari. Jenis parameter input RGB, luas cacat, energy, homogeneity, beras yang sering digunakan adalah beras putih. dan contrast didapatkan hasil akurasi sebesar $94 \%$ dari Gambar 2 merupakan contoh objek beras.

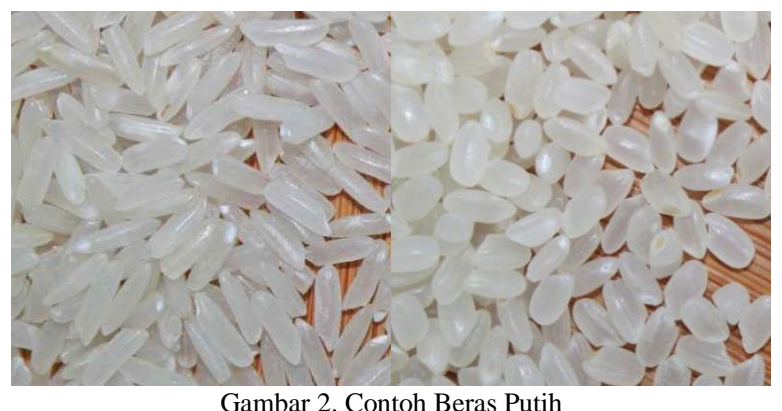

Masyarakat pada umumnya membedakan jenis baras dengan cara mengamati bentuk, ukurannya dan gradasi warna. Perbedaan gradasi warna ini menjadi fokus dalam penelitian ini melalui pengujian berbagai tingkat resolusi kamera yang digunakan dalam pengumpulan data citra beras untuk identifikasi jenis beras menggunakan kecerdasan buatan.

Jenis beras yang digunakan dalam penelitian ini adalah beras dengan sebutan beras pandan wangi, beras jawa barat, beras jawa timur, beras thailand, dan beras vietnam. Penelitian ini melakukan perbandingan tingkat akurasi pengenalan jenis beras putih berdasarkan beberapa resolusi kamera.

Salah satu metode pengenalan dari kecerdasan buatan yang digunakan untuk mengenali objek adalah Jaringan Syaraf Tiruan (JST). Jaringan Syaraf Tiruan adalah paradigma pengolahan informasi yang terinspirasi oleh

100 data uji pisang [6]. Penelitian identifikasi kematangan tomat dengan metode pengenalan jaringan syaraf tiruan backpropagation mendapatkan akurasi sebesar 71,67\% dari 60 data uji tomat[7].

Penelitian identifikasi buah apel envy dan apel pacific rose menggunakan metode pengenalan jaringan syaraf tiruan mendapatkan tingkat akurasi tertinggi sebesar $90 \%$ dengan data latih sebanyak 90 dan data uji sebanyak 10 untuk masing-masing jenis[8].

Penelitian tentang perbandingan jenis citra grayscale, HSV (Hue, Saturation, Value) dan L*a*b pada identifikasi buah pir dengan metode pengenalan jaringan syaraf tiruandengan ekstraksi ciri grayscale memperoleh hasil akurasi pengenalan sebesar 90\%, akurasi terbaik ekstraksi ciri HSV sebesar $100 \%$, dan akurasi terbaik dengan ekstraksi ciri $\mathrm{L}^{*} \mathrm{a} * \mathrm{~b}$ sebesar $100 \%$ [9].

Penelitian identifikasi varietas cabai berdasarkan morfologi daun dengan metode pengenalan jaringan syaraf tiruan mendapatkan rata-rata akurasi sebesar $97.92 \%$ [10].

Penelitian objek beras diantaranya klasifikasi mutu fisik beras menggunakan metode pengenalan JST dengan pembelajaran backpropagation. Model JST yang dikembangkan terdiri dari 10 parameter input, 20 hidden layer, dan 4 target. Keempat target tersebut terdiri dari butir utuh, butir kepala, butir patah dan butir menih. Rata-rata akurasi yang diperoleh sebesar $93,25 \%$ [11]. 
Penelitian identifikasi jenis beras berdasarkan hasil segmentasi deteksi tepi canny pada bentuk beras dengan metode pengenalan jaringan syaraf tiruan. Penelitian ini mendapatkan akurasi sebesar $70 \%$ pada arsitektur JST yang terdiri 400 input, 100 neuron pada hidden layer, dan 4 target output [12].

Penelitian klasifikasi 9 varietas beras dengan ekstraksi fitur berdasarka morfologi, warna dan tekstur sebagai parameter input jarinan syaraf tiruan mendapatkan hasil akurasi klasifikasi beras sebesar 92\% [13].

Penelitian klasifikasi beras philipina menggunakan machine vision dan metode pengenalan jaringan syaraf tiruan mendapatkan rata-rata akurasi keseluruhan sebesar 70\% [14].

Artikel ini memaparkan hasil penelitian yang berfokus pada perbandingan tingkat akurasi beberapa tingkat resolusi kamera pada pengenalan lima jenis beras putih dengan metode pengenalan jaringan syaraf tiruan dan ekstraksi ciri berasal dari GLCM (Gray Level Co Occurrence Matrix), sehingga penelitian ini menghasilkan referensi resolusi kamera yang sebaiknya digunakan dalam identifikasi jenis beras melalui citra, atau objek yang sejenis.

Beberapa teori dasar yang digunakan dalam kegiatan penelitian ini.

\section{a. Jaringan Syaraf Tiruan (JST)}

Jaringan Syaraf Tiruan atau ANN (Artificial Neural Network) adalah sebuah model jaringan yang meniru prinsip kerja dari neuron pada otak manusia. Terdapat dua model arsitektur JST, yaitu model arsitektur JST lapis tunggal (Gambar 3) dan model arsitektur JST lapis banyak atau multi layer (Gambar 4). Penelitian ini menggunakan JST multi layer.

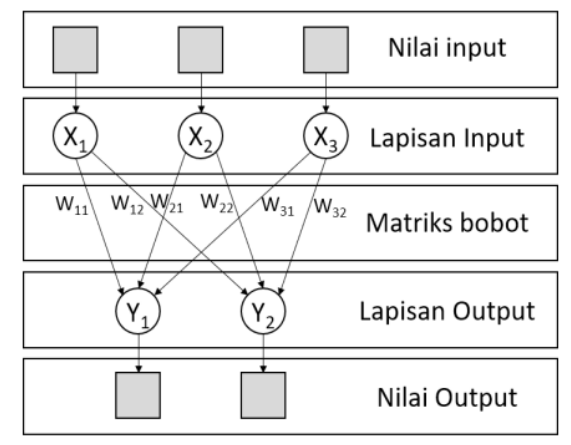

Gambar 3. Model Arsitektur JST Lapis Tunggal[3]

Gambar 3 dan 4 memiliki lapisan input, lapisan tersembunyi, dan lapisan output. Unit-unit lapisan input (Input Layer) bertugas menerima pola inputan dari luar yang menggambarkan suatu permasalahan. Unit-unit lapisan tersembunyi (Hidden Layer) memiliki nilai output yang tidak dapat diamati secara langsung. Unitunit lapisan output (OutputLayer) merupakan solusi JST terhadap suatu permasalahan [3].

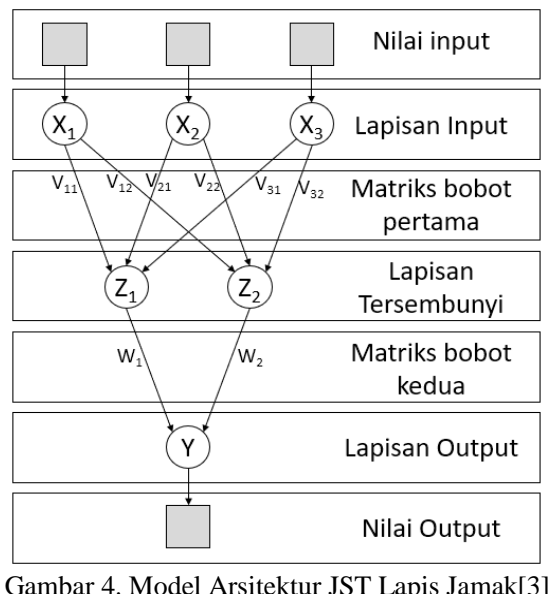

\section{b. Kamera sensor}

Faktor terpenting dalam menentukan kinerja kamera secara keseluruhan adalah ukuran sensor kamera, karena hal ini berpengaruh pada kualitas, warna, detail, dan tingkat noise pada gambar [15].

Sensor kamera, juga dikenal sebagai sensor gambar, adalah perangkat elektronik yang mengumpulkan informasi cahaya, terdiri dari warna \& intensitas setelah melewati pembukaan lensa, yang dikenal sebagai aperture. Kecepatan rana menentukan lamanya waktu informasi cahaya ini dikumpulkan oleh sensor kamera. ISO menentukan amplifikasi yang diterima informasi cahaya saat disampaikan ke dunia digital, tempat informasi itu disimpan pada kartu memori sebagai file gambar [15].

Ada dua jenis sensor gambar yang populer, sensor CMOS (semikonduktor oksida logam komplementer) \& sensor CCD (perangkat charge-coupled). Karena kinerja yang lebih tinggi, terutama dalam cahaya rendah, dan biaya lebih rendah Sensor CMOS ditemukan di hampir semua kamera digital modern. Sensor CMOS ditentukan oleh ukuran fisiknya (luas permukaan untuk menangkap informasi cahaya) dan jumlah piksel pengumpul informasi cahaya yang membentuk luas permukaan ini [15].

Gambar 5 merupakan contoh penampakan perangkat sensor kamera.

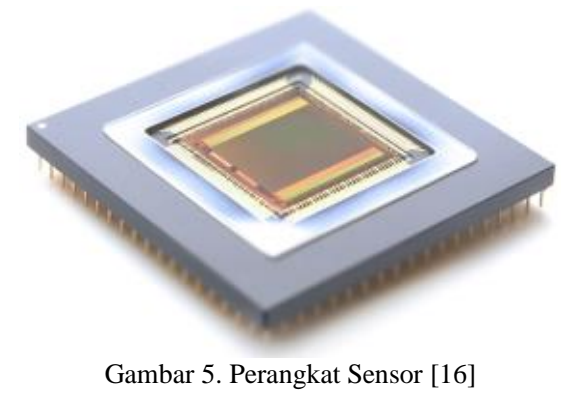

Cara kerja sensor kamera yaitu dengan cara menyaring (filter) berdasarkan panjang gelombang yang diterima. Panjang gelombang secara umum yang digunakan 
adalah merah, hijau, dan biru. Ilustrasi penyaringan panjang gelombang dapat dilihat pada Gambar 6.
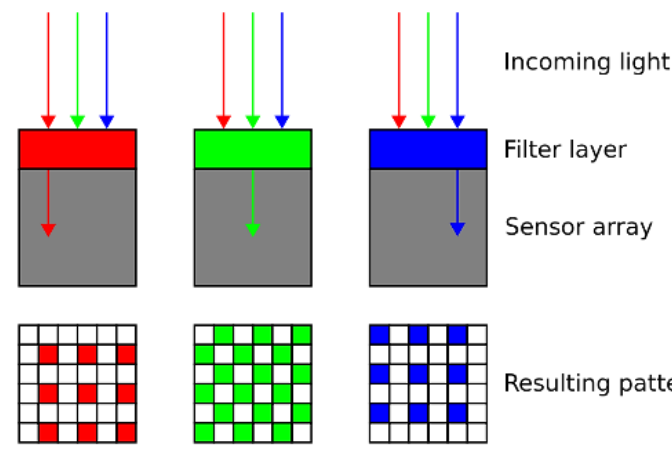

Resulting pattern

Gambar 6. Penyaringan Warna pada Sensor [17]

Gambar 6 menyajikan ilustrasi penyaringan gelombang cahaya yang masuk ke dalam sensor berdasarkan panjang gelombang yang diterima.

\section{c. Gray Level Co-Occurrence Matrix (GLCM)}

Gray Level Co-Occurrence Matrix merupakan metode ekstraksi ciri stastistik orde kedua untuk mendapatkan informasi pada citra [16]. Dengan cara menghitung frekuensi kemunculan pasangan piksel baik secara horizontal maupun vertikal. Prosen ini dapat dilihat pada Gambar 7.

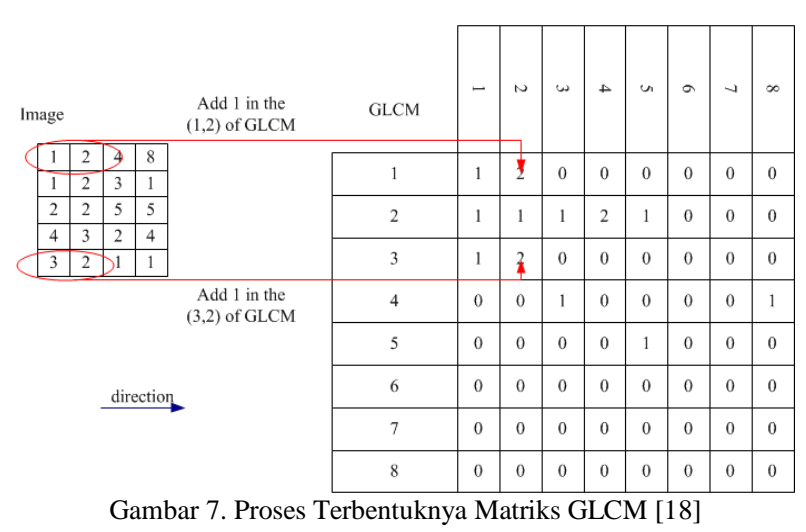

Gambar 7 merupakan contoh proses terbentuknya matrik GLCM. Matriks bagian kiri merupakan gambar ukuran $5 * 4$ dengan 8 level abu-abu. Matriks bagian kanan merupakan matriks hasil berukuran $8 * 8$ GLCM yang menghitung jumlah dua piksel dengan arah tertentu $\left(0^{\circ}\right)$ korelasi abu-abu [18].

Beberapa fitur yang diberikan GLCM antara lain [19].

1. Contrast

Merupakan nilai intensitas antara sebuah piksel terhadap tetangganya untuk seluruh piksel dalam citra menggunakan persamaan (1).

$$
\sum_{i, j}|i-j|^{2} p(i, j)
$$

2. Correlation

Merupakan sebuah nilai dari seberapa berkorelasinya sebuah piksel terhadap tetangganya untuk seluruh piksel dalam citra menggunakan persamaan (2)

$\sum_{i, j} \frac{(i-\mu i)(j-\mu j) p(i, j)}{\sigma_{i} \sigma_{j}}$

3. Energy

Merupakan sebuah nilai jumlah kuadrat elemen matriks GLCM menggunakan persamaan (3)

$$
\sum_{i, j} p(i, j)^{2}
$$

4. Homogeneity

Merupakan nilai yang kedekatan distribusi elemen dalam GLCM ke GLCM diagonal menggunakan persamaan (4)

$$
\sum_{i, j} \frac{p(i, j)}{1+|i-j|}
$$

\section{Definisi:}

$\mathrm{p}(\mathrm{i}, \mathrm{j})$ : GLCM value on element $(\mathrm{i}, \mathrm{j})$

$\mathrm{N}$ : Number of gray levels used in quantization process

: GLCM mean

$\sigma 2$ : The variance of the intensities of all reference pixels in the relationship that contributed to the GLCM

\section{Metode Penelitian}

Kerangka kerja dalam penelitian ini disajikan pada Gambar 8. Dengan tahapan sebagai berikut :

\section{Identifikasi Masalah}

Tahapan identifikasi masalah dimaksudkan guna mendapatkan masalah yang akan diselesaikan sehingga jalannya penelitian dan hasil penelitian tidak salah arah.

\section{Studi Literatur dan Pustaka}

Studi literatur bermaksud memposisikan penelitian ini terhadap penelitian sejenis yang sudah pernah dilakukan, sehingga tidak terjadi pengulangan penelitian atas masalah dan metode yang sama. Studi pustaka dilakukan guna mendapatkan teori-teori yang sudah dimuat dalam buku referensi.

\section{Pengumpulan data}

Penelitian ini menggunakan 5 jenis beras, yaitu beras (1) jawa barat, beras jawa timur, beras pandan wangi, beras thailand, dan beras vietnam. Gambar 9 sampai Gambar 
13 merupakan contoh beras yang digunakan pada penelitian ini.

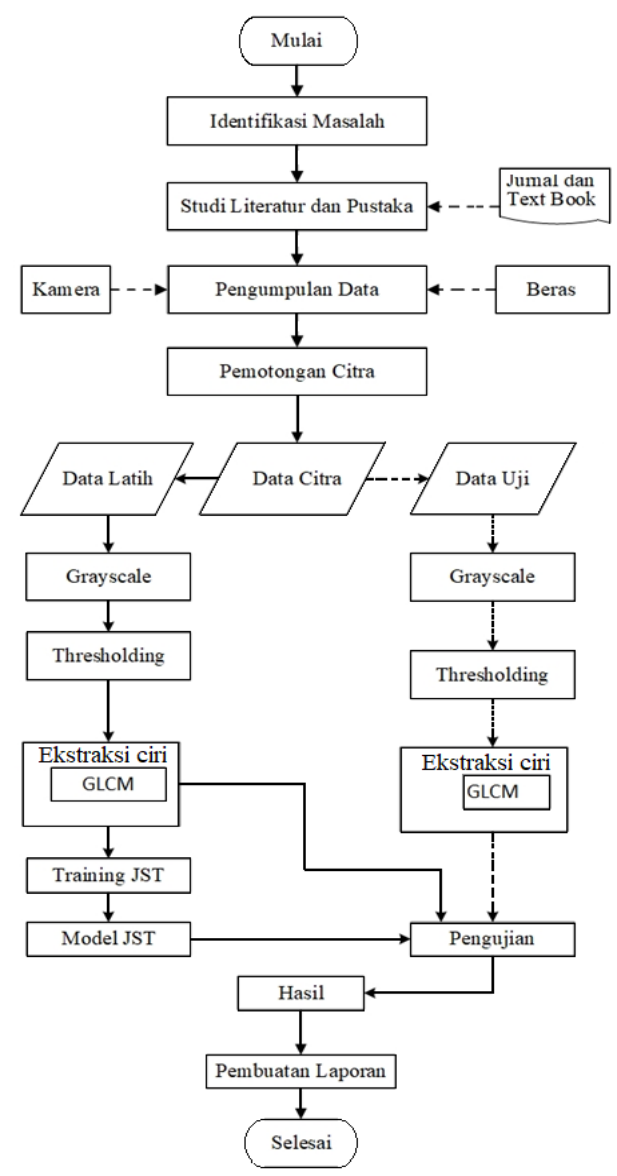

Gambar 8. Kerangka Kerja Penelitian

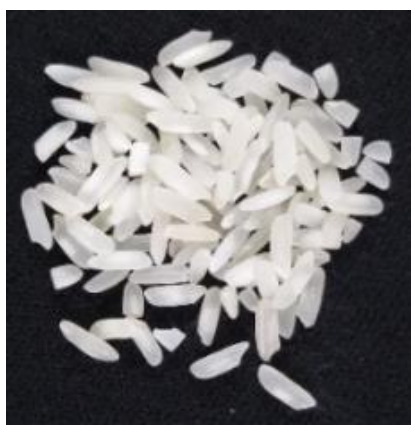

Gambar 9. Beras Pandan Wangi

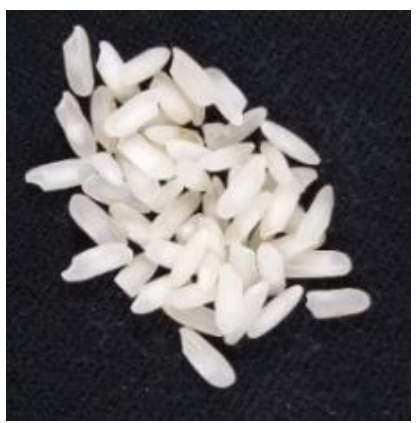

Gambar 10. Beras Jawa Barat

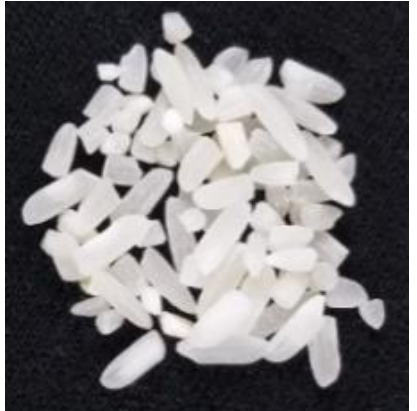

Gambar 11. Beras Jawa Timur

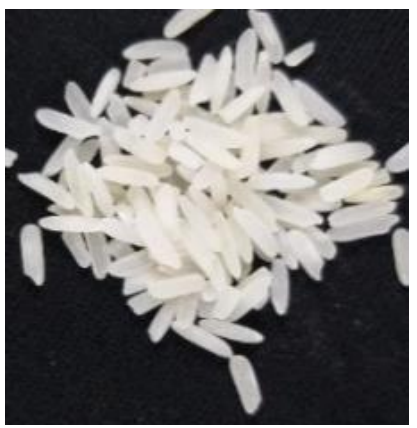

Gambar 12. Beras Thailand

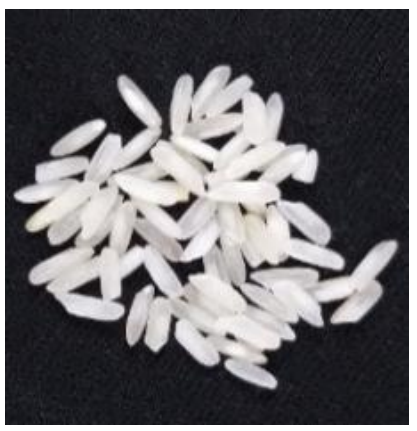

Gambar 13. Beras Vietnam

Pengumpulan data citra beras dilakukan dengan cara dipotret menggunakan kamera digital. Kamera yang digunakan terdiri dari 5 ukuran resolusi kamera yaitu 5MP (aperture f/2.2, sensor size 1/3"), 8 MP (aperture f/2.7), 12MP (aperture f/1.8, sensor size 1/2.8”), 14MP (aperture f/2.8 - 5.9, sensor size 1/2.3"), dan 16MP (aperture f/1.7, sensor size 1/2.8")

Pemotretan menggunakan sebuah kota dengan panjang $36 \mathrm{~cm}$, lebar $23 \mathrm{~cm}$, dan tinggi $9 \mathrm{~cm}$, dengan pencahayaan 2 lampu led dibagian sisi kiri dan kanan. Media pemotretan tampak bawah dapat dilihat pada Gambar 14, dan Gambar 15 menyajikan cara pemotretan yang dilakukan dari atas media pemotretan. Gambar 16 merupakan hasil pemotretan. 


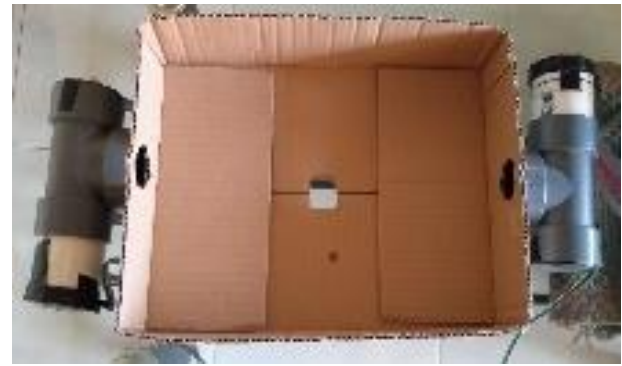

Gambar 14. Disain Perangkat Tempat Pemotretan (tampak bawah)

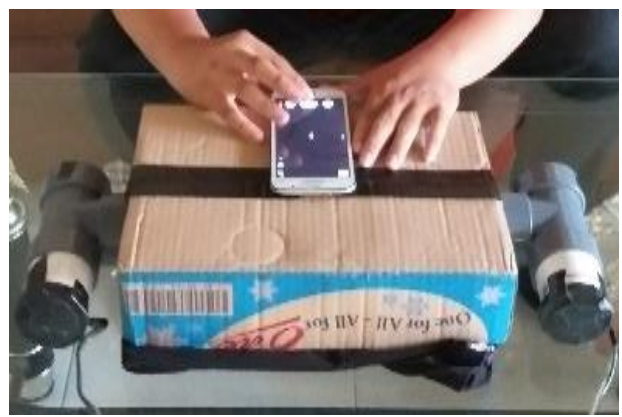

Gambar 15. Proses Pemotretan Objek Beras (tampak atas)

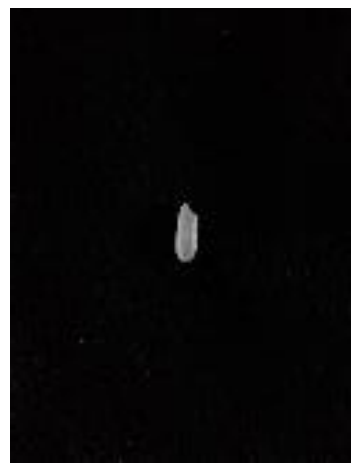

Gambar 16. Citra Hasil Pemotretan

\section{Pemotongan Citra / Cropping}

Hasil pemotretan memiliki latar belakang (background) yang sangat luas, dan ini mengganggu proses pelatihan dan pengujian, sehingga perlu adanya proses pengurangan atau bahkan penghilangan latar belakang.

Pemotongan citra bertujuan membuang latar belakang dari objek hasil pemotretan. Citra (Gambar 10) dipotong hingga batas objek dari 4 sisi, yaitu sisi atas, sisi kanan, sisi bawah, dan sisi kiri, sehingga tampak butir beras dengan sedikit latar yang masih tersisa. Citra hasil pemotongan dapat dilihar pada Gambar 17.

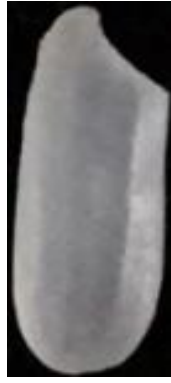

Gambar 17. Citra Hasil Pemotongan (Cropping)

\section{Data Citra}

Kumpulan citra hasil cropping dibagi menjadi data citra latih dan data citra uji. Data citra latih digunakan untuk melatih JST dalam mengenali jenis-jenis beras yang digunakan, sedangkan data citra uji digunakan untuk menguji JST yang sudah dilatih. Data citra latih (Tabel 1) sebanyak 75 buah dan data citra uji (Tabel 2) sebanyak 50 buah untuk masing-masing resolusi kamera.

Tabel 1. Data Latih

\begin{tabular}{lccccc}
\hline \multirow{2}{*}{ Jenis Beras } & \multicolumn{5}{c}{ Resolusi Kamera dalam Mega Piksel } \\
\cline { 2 - 6 } & 5 & 8 & 12 & 14 & 16 \\
\hline $\begin{array}{l}\text { Beras Jawa } \\
\text { Barat }\end{array}$ & 75 & 75 & 75 & 75 & 75 \\
\hline $\begin{array}{l}\text { Beras Jawa } \\
\text { Timur }\end{array}$ & 75 & 75 & 75 & 75 & 75 \\
\hline $\begin{array}{l}\text { Beras Pandan } \\
\text { Wangi }\end{array}$ & 75 & 75 & 75 & 75 & 75 \\
\hline Beras Thailand & 75 & 75 & 75 & 75 & 75 \\
\hline Beras Vietnam & 75 & 75 & 75 & 75 & 75 \\
\hline
\end{tabular}

Tabel 2. Data Uji

\begin{tabular}{lccccc}
\hline \multirow{2}{*}{ Jenis Beras } & \multicolumn{5}{c}{ Resolusi Kamera dalam Mega Piksel } \\
\cline { 2 - 6 } & 5 & 8 & 12 & 14 & 16 \\
\hline $\begin{array}{l}\text { Beras Jawa } \\
\text { Barat }\end{array}$ & 50 & 50 & 50 & 50 & 50 \\
\hline $\begin{array}{l}\text { Beras Jawa } \\
\text { Timur }\end{array}$ & 50 & 50 & 50 & 50 & 50 \\
\hline $\begin{array}{l}\text { Beras Pandan } \\
\text { Wangi }\end{array}$ & 50 & 50 & 50 & 50 & 50 \\
\hline Beras Thailand & 50 & 50 & 50 & 50 & 50 \\
\hline Beras Vietnam & 50 & 50 & 50 & 50 & 50 \\
\hline
\end{tabular}

\section{Grayscale dan Thresholding}

Mengubah citra dari RGB (Red, Green, Blue) menjadi grayscale. Grayscale adalah citra yang memiliki hanya satu nilai pada setiap pixelnya dimana warna yang dimiliki hanya warna hitam, keabuan dan putih serta citra grayscale memiliki kedalaman warna 8 bit (256 kombinasi warna keabuan) [12]. Selanjutnya dilakukan thresholding untuk menghilangkan informasi yang kurang penting dari citra sehingga hanya fokus ke citra berasnya saja. 
Berikut potongan program matlab untuk Grayscale dan Thresholding.

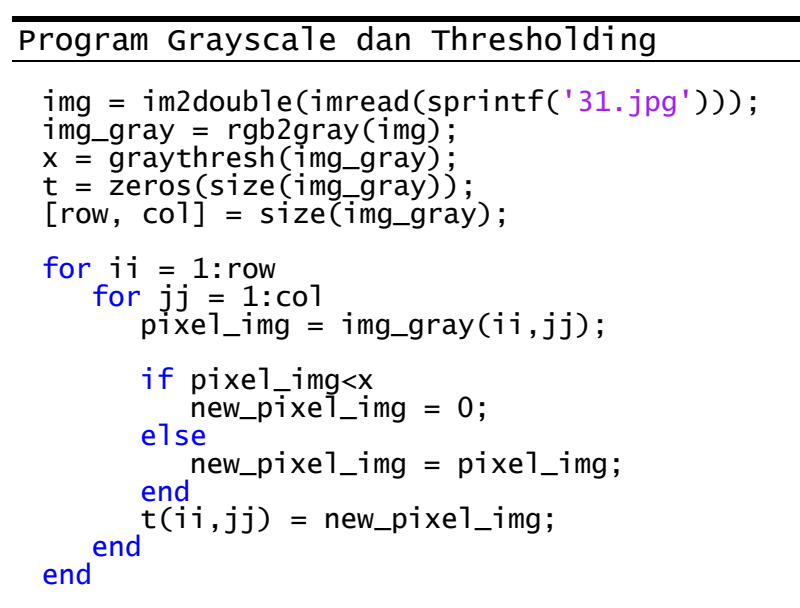

\section{Ekstraksi Ciri}

Ekstraksi ciri yang digunakan sebagai masukkan pada jaringan syaraf tiruan (JST) diperoleh dari hasil ekstraksi ciri (fitur)gray level co-occurrence matrix (GLCM). GLCM adalah metode ekstraksi ciri statistik orde kedua untuk mendapatkan informasi pada sebuah citra. Matriks GLCM adalah matriks yang merepresentasikan hubungan ketetanggaan antar piksel dalam sebuah citra pada berbagai arah orientasi dan jarak spasial [13].

Penelitian ini menggunakan 4 ciri dari GLCM, yaitu contrast, correlation, energy, homogeneity yang diekstrak dari sebuah citra hasil thresholding. Ekstrasksi ciri pada citra hasil thresholding diperoleh menggunakan kode program berikut.

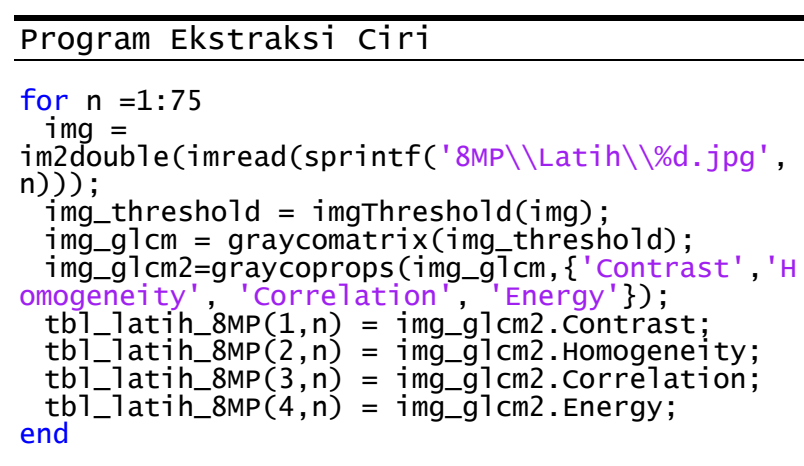

\section{Pelatihan JST}

Pelatihan JST dilakukan pada masing-masing resolusi kamera yaitu 5MP, 8MP, 12MP, 14MP dan 16MP. Data input JST berasal dari GLCM, yaitu contrast, energy, correlation, homogeneity. Sedangkan output JST terdiri dari 5 neuron dengan aturan output tersaji pada tabel definisi target pada Tabel 3. Pelatihan dilakukan beberapa kali terhadap beberapa arsitektur JST untuk mendapatkan arsitektur yang memiliki akurasi tertinggi.
Tabel 3. Definisi Target

\begin{tabular}{lccccc}
\hline & \multicolumn{5}{c}{ Target } \\
\cline { 2 - 6 } $\begin{array}{l}\text { Objek/ } \\
\text { keluaran }\end{array}$ & $\begin{array}{l}\text { Beras Beras } \\
\text { Bawa }\end{array}$ & $\begin{array}{l}\text { Beras } \\
\text { Barat }\end{array}$ & $\begin{array}{l}\text { Peras } \\
\text { Pandan }\end{array}$ & $\begin{array}{l}\text { Thailand } \\
\text { Wangi }\end{array}$ & Vietnam \\
\hline Beras Jawa Barat & 1 & 0 & 0 & 0 & 0 \\
Beras Jawa Timur & 0 & 1 & 0 & 0 & 0 \\
Beras Pandan & 0 & 0 & 1 & 0 & 0 \\
Wangi & 0 & 0 & 0 & 1 & 0 \\
Beras Thailand & 0 & 0 & 0 & 0 & 1 \\
Beras Vietnam & 0 & & & & \\
\hline
\end{tabular}

Tabel 3 menggambarkan output tiap neuron pada JST yang bermakna bahwa neuron yang bernilai 1 berarti dikenali sebagai beras tertentu sesuai baris dan kolom. Contoh, perhatikan kolom 2 (Beras Jawa Timur), dikenali sebagai beras jawa timur jika output neuron secara beurutan dari 1 s.d 5 : 01000 , artinya neuron output pertama bernilai nol, neuron output kedua bernilai satu, neuron output ketiga bernilai nol, neuron output keempat bernilai nol, dan neuron output kelima bernilai nol. Berikut contoh kode program digunakan untuk pelatihan 12MP, dan Gambar 18 merupakan gambaran perjalanan proses pelatihan.

Program Pelatihan JST

net_12MP $=$ newff(minmax (tb)_latih_12MP), [30 15

$80 \overline{5}$ ], \{' 'ogsig', 'logsig', ''logsig', ' logsig'\},

'traincgp');

init(net_12MP);

net_12MP.trainParam. epochs $=10000$

net $12 \mathrm{MP}$. trainParam. goa $1=1 \mathrm{e}-10$;

net_12MP.trainParam.min_grad=1e-30;

net_12MP.trainParam.min_step $=1 \mathrm{e}-06$;

net_12MP.trainParam. $1 r=0.0001$;

tic;

net5_12MP = train(net_12MP, tb1_1atih_12MP, target);

waktu_training $=$ toc;

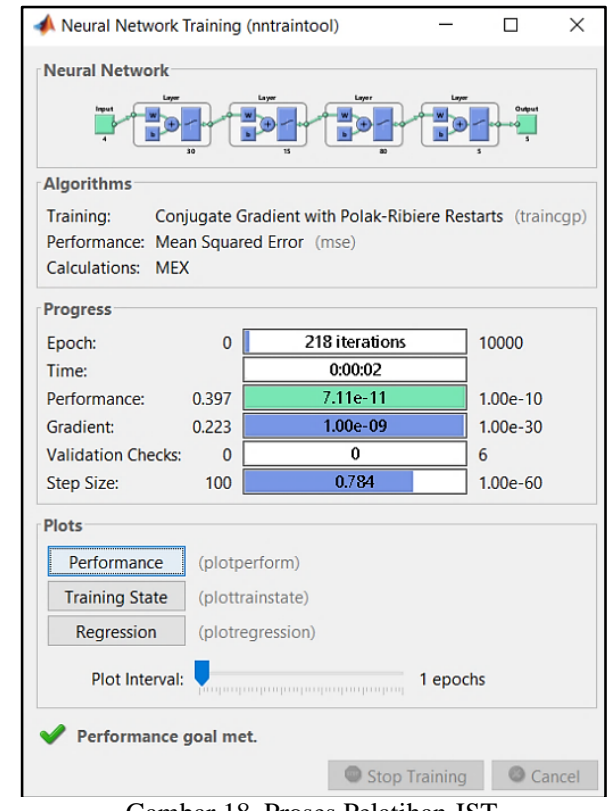

Gambar 18. Proses Pelatihan JST 


\section{Pengujian JST}

Pengujian dilakukan terhadap 50 citra uji untuk masing-masing jenis beras yang tidak digunakan pada proses pelatihan pembentukan JST. Pengujian dilakukan pada masing-masing tingkat resolusi kamera dengan menggunakan JST pada masing-masing tingkat resolusi kamera tersebut.

\section{Analisa Hasil}

Analisa hasil dari pengujian untuk mengetahui perbandingan tingkat akurasi pada setiap resolusi kamera dengan menggunakan confusion matriks menggunakan persamaan (5 s.d 7).

$$
\begin{aligned}
& \text { Akurasi }=\frac{T P+T N}{T P+T N+F P+F N} * 100 \% \\
& \text { Precision }=\frac{T P}{F P+T P} * 100 \% \\
& \text { Recall }=\frac{T P}{F N+T P} * 100 \%
\end{aligned}
$$

Definisi :

Accuracy : Perbandingan kasus yang diidentifikasi benar dengan jumlah semua kasus

Precision : Proporsi kasus dengan hasil positif yang benar.

Recall : Proporsi kasus positif yang diidentifikasi dengan benar.

TN : True Negative, merupakan jumlah data negatif yang terdeteksi dengan benar,

FP : False Positive, merupakan data negatif namun terdeteksi sebagai data positif.

TP : True Positive, merupakan data positif yang terdeteksi benar.

FN
Tabel 4 menunjukkan bahwa arsitektur JST untuk tiap tingkat resolusi kamera adalah berbeda, hal ini dikarenakan arsitektur-asitektur tersebut merupakan arsitektur terbaik (akurasi pengenalan terbaik) untuk masing-masing tingkat resolusi kamera.

Gambar 19 merupakan contoh arsitektur JST yang terbentuk dengan tiga hidden layer. Banyaknya neuron pada tiap hidden layer (Gambar 14) mengacu Tabel 4.

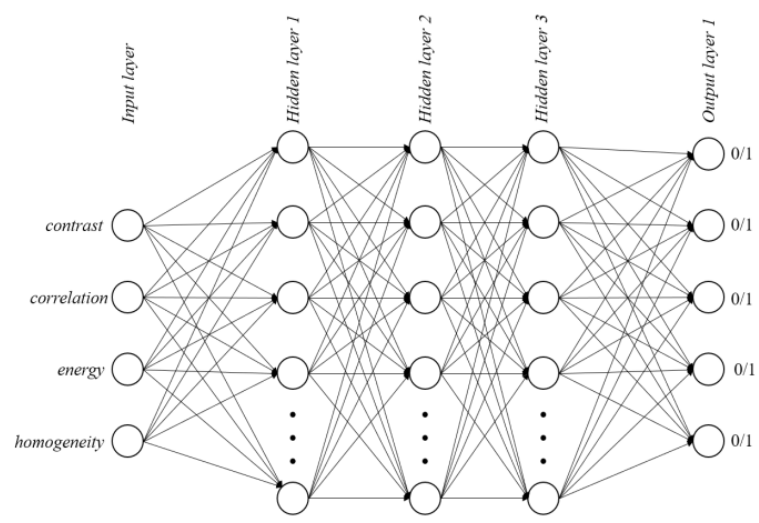

Gambar 19. Contoh Arsitektur JST

\section{Hasil Pengujian}

Pengujian dilakukan pada semua jenis beras yang masing-masing terdiri dari 10 citra, sehingga secara keseluruhan terdapat 50 citra uji. Citra yang digunakan untuk pengujian adalah citra yang tidak digunakan pada saat pelatihan JST. Pengujian ini dilakukan pada setiap resolusi kamera.

Hasil pengujian untuk masing-masing model JST disajikan pada Tabel 5sampai Tabel 9. Tabel dengan arsitektur JST 3 hiddenlayer, yaitu hiddenlayer True Positive, sehingga data posifit, namun neuron, dan hiddenlayer 3 memiliki 15 neuron. terdeteksi sebagai data negatif.

\section{Hasil dan Pembahasan}

Arsitektur JST hasil pelatihan untuk masing-masing tingkat resolusi kamera dapat dilihat pada Tabel 4.

Tabel 4. Arsitektur JST Hasil Pelatihan

\begin{tabular}{|c|c|c|c|c|c|c|c|}
\hline \multirow{2}{*}{$\begin{array}{l}\text { Jenis } \\
\text { Beras }\end{array}$} & \multirow[b]{2}{*}{$\mathrm{TP}$} & \multirow[b]{2}{*}{$\mathrm{FP}$} & \multirow[b]{2}{*}{ FN } & \multirow[b]{2}{*}{$\mathrm{TN}$} & \multicolumn{3}{|c|}{ Hasil (\%) } \\
\hline & & & & & $\begin{array}{l}\text { Accu } \\
\text { racy }\end{array}$ & $\begin{array}{l}\text { Preci } \\
\text { sion }\end{array}$ & Recall \\
\hline $\begin{array}{l}\text { Beras Jawa } \\
\text { Barat }\end{array}$ & 4 & 3 & 6 & 37 & 82 & 57 & 40 \\
\hline $\begin{array}{l}\text { Beras Jawa } \\
\text { Timur }\end{array}$ & 5 & 5 & 5 & 35 & 80 & 50 & 50 \\
\hline $\begin{array}{l}\text { Beras } \\
\text { Pandan } \\
\text { Wangi }\end{array}$ & 5 & 8 & 5 & 32 & 74 & 38 & 50 \\
\hline $\begin{array}{l}\text { Beras } \\
\text { Thailand }\end{array}$ & 0 & 2 & 10 & 38 & 76 & 0 & 0 \\
\hline $\begin{array}{l}\text { Beras } \\
\text { Vietnam }\end{array}$ & 2 & 12 & 8 & 28 & 60 & 14 & 20 \\
\hline Rata - Rata & & & & & 74 & 32 & 32 \\
\hline $\begin{array}{l}\text { Keterangan } \\
\text { (False Nega }\end{array}$ & $\begin{array}{l}\mathrm{TP} \\
e),\end{array}$ & $\begin{array}{l}\text { rue } \\
\mathrm{TN}\end{array}$ & siti & $\begin{array}{l}\text { FP } \\
\text { gative }\end{array}$ & False & ositive & ), $\mathrm{FN}$ \\
\hline
\end{tabular}

\begin{tabular}{lccccr}
\hline Arsitektur JST & \multicolumn{6}{c}{ Resolusi Kamera dalam Mega Piksel } \\
\cline { 2 - 6 } & 5 & 8 & 12 & 14 & 16 \\
\hline $\begin{array}{l}\text { Banyaknya neuron pada } \\
\text { Input Layer }\end{array}$ & 4 & 4 & 4 & 4 & 4 \\
$\begin{array}{l}\text { Banyaknya Hidden Layer } \\
\begin{array}{l}\text { Banyaknya neuron pada } \\
\text { Hidden Layer 1 }\end{array}\end{array}$ & 3 & 3 & 3 & 3 & 3 \\
$\begin{array}{l}\text { Banyaknya neuron pada } \\
\text { Hidden Layer 2 }\end{array}$ & 15 & 35 & 15 & 80 & 90 \\
$\begin{array}{l}\text { Banyaknya neuron pada } \\
\text { Hidden Layer 3 }\end{array}$ & 15 & 35 & 15 & 80 & 90 \\
$\begin{array}{l}\text { Banyaknya neuron pada } \\
\text { Output Layer }\end{array}$ & 5 & 5 & 5 & 5 & 50 \\
\hline
\end{tabular}

Tabel 5. Hasil Pengujian JST untuk Resolusi Kamera 5MP 
Berdasarkan Tabel 5 diketahui setelah dilakukan Tabel 7 menunjukkan hasil perhitungan confusion perhitungan confusion matrix didapatkan hasil rata - matrixuntuk resolusi 12MP, yaitu rata-rata accuracy rata accuracy sebesar 78\%, rata - rata precision sebesar sebesar $82 \%$, rata - rata precision sebesar $55 \%$ dan rata $42 \%$ dan rata-rata recall sebesar $34 \%$.

- rata recall sebesar $50 \%$.

Tabel 6 merupakan hasil dari pengujian untuk resolusi Tabel 8 merupakan data hasil dari pengujian untuk 8MP, dengan arsitektur JST 3 hiddenlayer, yaitu resolusi 14MP, dengan arsitektur JST 3 hiddenlayer, hiddenlayer 1 memiliki 35 neuron, hiddenlayer 2 yaitu hiddenlayer 1 memiliki 80 neuron, hiddenlayer 2 memiliki 35 neuron, dan hiddenlayer 3 memiliki 35 memiliki 80 neuron, dan hiddenlayer 3 memiliki 105 neuron.

Tabel 6. Hasil Pengujian JST untuk Resolusi Kamera 8MP

\begin{tabular}{|c|c|c|c|c|c|c|c|}
\hline \multirow{2}{*}{$\begin{array}{r}\text { Jenis } \\
\text { Beras }\end{array}$} & \multirow[b]{2}{*}{$\mathrm{TP}$} & \multirow[b]{2}{*}{ FP } & \multirow[b]{2}{*}{ FN } & \multirow[b]{2}{*}{$\mathrm{TN}$} & \multicolumn{3}{|c|}{ Hasil (\%) } \\
\hline & & & & & $\begin{array}{l}\text { Accu } \\
\text { racy }\end{array}$ & $\begin{array}{l}\text { Preci } \\
\text { sion }\end{array}$ & Recall \\
\hline $\begin{array}{l}\text { Beras Jawa } \\
\text { Barat }\end{array}$ & 5 & 3 & 5 & 37 & 84 & 63 & 50 \\
\hline $\begin{array}{l}\text { Beras Jawa } \\
\text { Timur }\end{array}$ & 6 & 13 & 4 & 27 & 66 & 32 & 60 \\
\hline $\begin{array}{l}\text { Beras } \\
\text { Pandan } \\
\text { Wangi }\end{array}$ & 1 & 8 & 9 & 32 & 66 & 11 & 10 \\
\hline $\begin{array}{l}\text { Beras } \\
\text { Thailand }\end{array}$ & 0 & 2 & 10 & 38 & 76 & 0 & 0 \\
\hline $\begin{array}{l}\text { Beras } \\
\text { Vietnam }\end{array}$ & 1 & 9 & 9 & 31 & 64 & 10 & 10 \\
\hline Rata - Rata & & & & & 71 & 23 & 26 \\
\hline $\begin{array}{l}\text { Keterangan } \\
\text { (False Nega }\end{array}$ & $\begin{array}{l}\mathrm{TP} \\
e), \mathrm{d}\end{array}$ & $\begin{array}{l}\text { ue } \\
\text { TN }\end{array}$ & ue & $\begin{array}{l}\mathrm{FP} \\
\text { ativ }\end{array}$ & alse & Positil & , FN \\
\hline
\end{tabular}

Tabel 6 menunjukkan hasil perhitungan confusion matrixdengan masing-masing hasil rata-rata accuracy sebesar $71 \%$, rata - rata precision sebesar $23 \%$ dan rata - rata recall sebesar $26 \%$.

Tabel 7 menyajikan data hasil dari pengujian untuk resolusi 12MP, dengan arsitektur JST 3 hiddenlayer, yaitu hiddenlayer 1 memiliki 15 neuron, hiddenlayer 2 memiliki 15 neuron, dan hiddenlayer 3 memiliki 30 neuron.

Tabel 7. Hasil Pengujian JST untuk Resolusi Kamera 12MP

\begin{tabular}{|c|c|c|c|c|c|c|c|}
\hline \multirow{2}{*}{$\begin{array}{l}\text { Jenis } \\
\text { Beras }\end{array}$} & \multirow[b]{2}{*}{$\mathrm{TP}$} & \multirow[b]{2}{*}{ FP } & \multirow[b]{2}{*}{ FN } & \multirow[b]{2}{*}{$\mathrm{TN}$} & \multicolumn{3}{|c|}{ Hasil (\%) } \\
\hline & & & & & $\begin{array}{l}\text { Accu } \\
\text { racy }\end{array}$ & $\begin{array}{l}\text { Preci } \\
\text { sion }\end{array}$ & Recall \\
\hline $\begin{array}{l}\text { Beras Jawa } \\
\text { Barat }\end{array}$ & 2 & 4 & 8 & 36 & 76 & 33 & 20 \\
\hline $\begin{array}{l}\text { Beras Jawa } \\
\text { Timur }\end{array}$ & 3 & 8 & 7 & 32 & 70 & 27 & 30 \\
\hline $\begin{array}{l}\text { Beras } \\
\text { Pandan } \\
\text { Wangi }\end{array}$ & 8 & 4 & 2 & 36 & 88 & 67 & 80 \\
\hline $\begin{array}{l}\text { Beras } \\
\text { Thailand }\end{array}$ & 4 & 4 & 6 & 36 & 80 & 50 & 40 \\
\hline $\begin{array}{l}\text { Beras } \\
\text { Vietnam }\end{array}$ & 8 & 0 & 2 & 40 & 96 & 100 & 80 \\
\hline Rata - Rata & & & & & 82 & 55 & 50 \\
\hline $\begin{array}{l}\text { Keterangan } \\
\text { (False Nega }\end{array}$ & , & 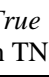 & 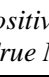 & 1 & alse & osit & $\mathrm{F}$ \\
\hline
\end{tabular}
neuron

Tabel 8 menyajikan data hasil perhitungan confusion matrixhasil pengujian untuk resolusi 14MP, yaitu ratarata accuracy sebesar $78 \%$, rata - rata precision sebesar $42 \%$ dan rata - rata recall sebesar $34 \%$.

Tabel 8. Hasil Pengujian JST untuk Resolusi Kamera 14MP

\begin{tabular}{|c|c|c|c|c|c|c|c|}
\hline \multirow{2}{*}{$\begin{array}{l}\text { Jenis } \\
\text { Beras }\end{array}$} & \multirow[b]{2}{*}{$\mathrm{TP}$} & \multirow[b]{2}{*}{ FP } & \multirow[b]{2}{*}{ FN } & \multirow[b]{2}{*}{$\mathrm{TN}$} & \multicolumn{3}{|c|}{ Hasil (\%) } \\
\hline & & & & & $\begin{array}{l}\text { Accu } \\
\text { racy }\end{array}$ & $\begin{array}{l}\text { Preci } \\
\text { sion }\end{array}$ & Recall \\
\hline $\begin{array}{l}\text { Beras Jawa } \\
\text { Barat }\end{array}$ & 2 & 3 & 8 & 37 & 78 & 40 & 20 \\
\hline $\begin{array}{l}\text { Beras Jawa } \\
\text { Timur }\end{array}$ & 2 & 4 & 8 & 36 & 76 & 33 & 20 \\
\hline $\begin{array}{l}\text { Beras } \\
\text { Pandan } \\
\text { Wangi }\end{array}$ & 5 & 5 & 5 & 35 & 80 & 50 & 50 \\
\hline $\begin{array}{l}\text { Beras } \\
\text { Thailand }\end{array}$ & 4 & 6 & 6 & 34 & 76 & 40 & 40 \\
\hline $\begin{array}{l}\text { Beras } \\
\text { Vietnam }\end{array}$ & 4 & 5 & 6 & 35 & 78 & 44 & 40 \\
\hline Rata - Rata & & & & & 78 & 42 & 34 \\
\hline $\begin{array}{l}\text { Keterangan } \\
\text { (False Nega }\end{array}$ & $\begin{array}{l}\mathrm{TP} \\
e),\end{array}$ & $\begin{array}{l}\text { ue } \\
\text { TN }\end{array}$ & $\begin{array}{l}\text { iti } \\
\text { ue }\end{array}$ & $\begin{array}{l}\text { FP } \\
\text { ative }\end{array}$ & False & ositi & ), FN \\
\hline
\end{tabular}

Tabel 9 menyajikan data hasil pengujian untuk resolusi 16MP, dengan arsitektur JST 3 hiddenlayer, yaitu hiddenlayer 1 memiliki 90 neuron, hiddenlayer 2 memiliki 90 neuron, dan hiddenlayer 3 memiliki 80 neuron.

Tabel 9. Hasil Pengujian JST untuk Resolusi Kamera 16MP

\begin{tabular}{|c|c|c|c|c|c|c|c|}
\hline \multirow{2}{*}{$\begin{array}{r}\text { Jenis } \\
\text { Beras }\end{array}$} & \multirow[b]{2}{*}{$\mathrm{TP}$} & \multirow[b]{2}{*}{ FP } & \multirow[b]{2}{*}{$\mathrm{FN}$} & \multirow[b]{2}{*}{$\mathrm{TN}$} & \multicolumn{3}{|c|}{ Hasil (\%) } \\
\hline & & & & & $\begin{array}{l}\text { Accu } \\
\text { racy }\end{array}$ & $\begin{array}{l}\text { Preci } \\
\text { sion }\end{array}$ & Recall \\
\hline $\begin{array}{l}\text { Beras Jawa } \\
\text { Barat }\end{array}$ & 3 & 4 & 7 & 36 & 78 & 43 & 30 \\
\hline $\begin{array}{l}\text { Beras Jawa } \\
\text { Timur }\end{array}$ & 2 & 8 & 8 & 32 & 68 & 20 & 20 \\
\hline $\begin{array}{l}\text { Beras } \\
\text { Pandan } \\
\text { Wangi }\end{array}$ & 4 & 6 & 6 & 34 & 76 & 40 & 40 \\
\hline $\begin{array}{l}\text { Beras } \\
\text { Thailand }\end{array}$ & 4 & 2 & 6 & 38 & 84 & 67 & 40 \\
\hline $\begin{array}{l}\text { Beras } \\
\text { Vietnam }\end{array}$ & 2 & 7 & 8 & 33 & 70 & 66 & 20 \\
\hline Rata - Rata & & & & & 75 & 38 & 30 \\
\hline $\begin{array}{l}\text { Keterangan } \\
\text { (False Nega }\end{array}$ & TP & $\mathrm{TN}$ & ce 1 & Fl & alse & osit & ), FN \\
\hline
\end{tabular}

Tabel 9 menyajikan data hasil pengujian untuk resolusi $16 \mathrm{MP}$, yaitu rata-rata accuracy sebesar $75 \%$, rata - rata 
precision sebesar $38 \%$ dan rata - rata recall sebesar $30 \%$.

Bedasarkan hasil pengujian yang disajikan pada Tabel 5 sampai dengan Tabel 9, maka hasil terbaik didapatkan pada resolusi kamera $12 \mathrm{MP}$, yaitu rata-rata accuracy sebesar $82 \%$, rata - rata precision sebesar [7] $85 \%$, dan rata - rata recall sebesar $50 \%$. Tingkat resolusi lainnya memberikan tingkat akurasi lebih rendah, hal ini kemungkinan terjadi karena pada $5 \mathrm{MP}$ dan 8 MP menghasilkan citra yang masih terlalu kasar, sehingga gradasi warna citra tidak dapat mewakili jenis beras. Sedangkan pada resolusi $14 \mathrm{MP}$ dan $16 \mathrm{MP}$ menghasilkan citra yang terlalu halus, sehingga tingkat gradasi warna citra terlalu tinggi, sehingga membuat JST sulit untuk membedakan antar jenis beras tersebut berdasarkan fitur yang digunakan.

\section{Kesimpulan}

Resolusi 12 MP memberikan hasil terbaik diantara resolusi lainnya. Hal ini dapat diamati pada Tabel 5 s.d Tabel 9. Resolusi kamera berpengaruh pada tingkat pengenalan, hal ini dikarenakan perbedaan tingkat gradasi warna yang dihasilkan dari masing-masing resolusi kamera. Tingkat gradasi warna dari resolusi kamera ini juga menyebabkan arsitektur JST yang berbeda untuk mendapatkan hasil terbaik untuk masing-masing tingkat resolusi kamera. Tingkat akurasi terbaik pada resolusi $12 \mathrm{MP}$, dan tingkat akurasi pengenalan turun jika tingkat resolusi dinaikkan menjadi 14 MP dan 16 MP. Hal ini menunjukkan bahwa terdapat kaitan antara tingkat resolusi kamera yang digunakan dengan gradasi warna beras pada identifikasi jenis beras melalui citra. Sehingga dalam kasus ini dapat disimpulkan bahwa, semakin tinggi tingkat resolusi kamera maka tidak berarti semakin tinggi juga tingkat akurasi pengenalannya.

Adapun saran yang dapat dilakukan pada penelitian selanjutnya adalah sebaiknya melakukan praproses pada citra sebelum dilakukan ekstraksi ciri.

\section{Daftar Rujukan}

[1] Wikimedia, 2019.Mina Padi Java. [Online] (Update 12 Mar 2019) Tersedia di :https://upload.wikimedia.org/wikipedia/commons/4/43/Mina_ padi_java_Pj_IMG-20150313-WA0004.jpg

[2] Oryza sativa L.,2019. Rice. [Online] (Update 22 Feb 2019) Tersedia di : https://www.shajithdarshana.com/2013/07/oryzasativa-1-rice.html

[3] Sutojo T, Mulyanto E, dan Vincent, 2010.Kecerdasan Buatan. Yogyakarta: Andi Offset.

[4] Agmalaro MA, Kustiyo A, dan Akbar AR., 2013.Identifikasi Tanaman Buah Tropika Berdasarkan Tekstur Permukaan Daun Menggunakan Jaringan Syaraf Tiruan. Jurnal Ilmu Komputer Agri-Informatika,2(2), pp.73-82. doi:http://dx.doi.org/10.29244/jika.2.2.73-82

[5] Adnan, Suhartini, Kusbiantoro B, 2013. Identifikasi Varietas Berdasarkan Warna dan Tekstur Permukaan Beras Menggunakan Pengolahan Citra Digital dan Jaringan Syaraf
Tiruan. Jurnal Penelitian Pertanian Tanaman Pangan, 32(2), pp.91-97.

[6] Wiharja PW, Harjoko A., 2014.Pemrosesan Citra Digital untuk Klasifikasi Mutu Buah Pisang Menggunakan Jaringan Saraf Tiruan. Indonesian Journal of Electronics and Instrumentations System (IJEIS), 4(4), pp.57-68. doi:https://doi.org/10.22146/ijeis.4222

Deswari D, Hendrick M, dan Derisma M., 2013.Identifikasi Kematangan Buah Tomat Menggunakan Metoda Backpropagation. [Online]( Update 22 Feb 2019)

Tersedia di : http://repo.unand.ac.id/id/eprint/269

[8] Rahmanti FZ, Adi PW, Ataka I, dan Sukmana SE., 2016. Pengembangan Tahapan Klasifikasi Apel Envy dan Pasific Rose Menggunakan Jaringan Saraf Tiruan. Jurnal Nasional Teknik Elektro (JNTE), 5(2), pp.237-243. Doi:10.20449/jnte.v5i2.283

[9] Octavia M, Jessyln, dan Gasim, 2016, Perbandingan Tingkat Akurasi Jenis Citra Keabuan, HSV, dan L*a*b pada Identifikasi Jenis Buah Pir. Jurnal Ilmiah Informatika Global, 7(1),

11.http://ejournal.uigm.ac.id/index.php/IG/article/view/143 pp.7-

[10] Syaban K, dan Harjoko A., 2016, Klasifikasi Varietas Cabai Berdasarkan Morfologi Daun Menggunakan Backpropagation Neural Network. Indonesian Journal of Computing and Cybernetics System (IJCCS), 10(2), pp. 161-172. doi:https://doi.org/10.22146/ijccs.16628

[11] Somantri AS., 2010, Menentukan Klasifikasi Mutu Fisik Beras dengan Menggunakan Teknologi Pengolahan Citra Digital dan Jaringan Syaraf Tiruan. Jurnal Standardisasi, 12(3), pp.162173. doi:http://dx.doi.org/10.31153/js.v12i3.154

[12] Qoriah R, 2017.Identifikasi Jenis Beras Menggunakan Metode Backpropagation neuron network. [Online](Update 24Feb 2019)

Tersedia di : http://eprints.akakom.ac.id/5943

[13] C.S. Silva and U. Sonnadara, 2013. Classification of Rice Grains Using Neural Networks, in Proceedings of Technical Sessions.

[14] J.D. Guzman and E.K. Peralta, 2008. Classification of Philippine Rice Grains Using Machine Vision and Artificial Neural Networks, World conference on agricultural information and IT, IAALD AFITA WCCA.

[15] D. Morrow. 2019.Camera Sensor Size Photography Guide. [Online](Update 22 Feb 2019)

Tersedia

:https://www.davemorrowphotography.com/camera-sensorsize-guide

[16] H. Tiarks. 2019. CCD vs. CMOS: What Are the New Trends?. [Online](Update 22 Feb 2019)

Tersedia di: https://www.baslerweb.com/en/visioncampus/camera-technology/cmos-ccd-technology

[17] CML. Burnett. 2006. Cross-Section of a Bayer Filter. [Online] (Update 22 Feb 2019)

Tersedia di :

https://commons.wikimedia.org/wiki/File:Bayer_pattern_on_s ensor_profile.svg

[18] J. Lin, L. Zhu, Z. Chen and X. Chen, 2015, Objective Quality Assessment for Image Retargeting Based on Hybrid Distortion Pooled Model,Seventh International Workshop on Quality of Multimedia Experience (QoMEX), Pylos-Nestoras. pp. 1-6, doi: 10.1109/QoMEX.2015.7148090

[19] Mathworks Inc., 2018.Graycoprops. [Online] ( Update 23 Feb 2019)

Tersedia di :

https://www.mathworks.com/help/images/ref/graycoprops.htm 1

Jurnal RESTI (Rekayasa Sistem dan Teknologi Informasi) Vol. 3 No. 2 (2019) 131 - 140 